\title{
HUBUNGAN ANTARA LITERASI SAINS DENGAN PRESTASI BELAJAR PESERTA DIDIK PADA PEMBELAJARAN KIMIA KELAS XI MIPA SMA NEGERI SE-KOTA MAKASSAR
}

\author{
Andi Ratna Khaerati Armas ${ }^{1}$, Ramlawati ${ }^{2}$, Muhammad Syahrir ${ }^{3}$ \\ ${ }^{1}$ Guru Kimia SMA Ummul Mukminin \\ ${ }^{2,3}$ Dosen Program Pascasarjana Universitas Negeri Makassar \\ Email: andiratnaarmas1991@gmail.com
}

\begin{abstract}
ABSTRAK
Penelitian ini merupakan penelitian ex-post facto yang bertujuan untuk menentukan hubungan antara literasi sains dengan prestasi belajar peserta didik pada pembelajaran kimia kelas XI MIPA SMA Negeri Se-Kota Makassar tahun pelajaran 2017/2018. Populasi penelitian sebanyak 1734 peserta didik dengan jumlah sampel sebanyak 391 peserta didik. Teknik pengambilan sampel dilakukan dengan menggunakan proportionate stratified random sampling. Pengambilan data penelitian menggunakan instrumen tes literasi sains dan data prestasi belajar peserta didik berupa nilai rapor mata pelajaran kimia semester genap tahun pelajaran 2017/2018. Data penelitian menggunakan analisis korelasi Pearson. Hasil penelitian menunjukkan bahwa literasi sains memiliki hubungan positif dengan prestasi belajar peserta didik dengan tingkat korelasi sedang.
\end{abstract}

Kata kunci : literasi sains, prestasi belajar.

\begin{abstract}
The study is ex-post factor research, which aims to determining the correlation between scientific literacy toward students' learning achievement on chemistry learning of grade XI MIPA at SMAN (public senior high schools) in Makassar of academic year 2017/2018. The Population of the study were 1734 students and the samples were 391 students obtained by employing proportionate stratified random sampling technique. Data were collected using instruments of scientific literacy test, and sata of students' learning achievement was obtained from report score of Chemistry subject of academic year 2017/2018. Data were analyzed by using Pearson correlationanalysis and multiple regression analysis. The result of the study reveal that the scientific literacy has positive correlation toward students' learning achievement with correlation.
\end{abstract}

Keywords: scientific literacy, learning achievement.

\section{PENDAHULUAN}

Pendidikan merupakan tolak ukur dalam menentukan kemajuan suatu bangsa. Pendidikan pada abad 21 ini mendorong generasi muda untuk dapat mengembangkan potensi dirinya dengan terus berinovasi dan berkarya sehingga bisa tetap survive dalam menghadapi persaingan globalisasi. Menurut
Abdullah and Osman (2010), ide dasar pendidikan adalah membangun manusia supaya bisa survive melindungi diri terhadap alam serta mengatur hubungan antarmanusia, terlebih ketika pendidikan dihadapkan pada era dimana setiap orang harus berkompetisi pada berbagai sektor kehidupan. Untuk dapat tetap survive 
terhadap perkembangan jaman, kita harus mengubah proses belajar anak dan melibatkan mereka dalam memperoleh keterampilan dan pengetahuannya. Salah satu hal yang harus dilakukan dalam menghadapi persaingan pada era ini adalah "melek" terhadap sains (scientific literacy) yaitu kemampuan seseorang dalam memahami, mengkomunikasikan, serta mengaplikasikan konsep-konsep sains dalam kehidupan nyata. Literasi sains berarti seseorang memiliki kemampuan untuk menggambarkan, menjelaskan, dan memprediksi fenomena-fenomena alam (National Research Council, 1996). Menurut Gormally et al. (2012), kemampuan literasi sains diartikan sebagai kemampuan seseorang untuk membedakan fakta-fakta sains dari bermacam-macam informasi, mengenal dan menganalisis penggunaan metode penyelidikan saintifik serta kemampuan untuk mengorganisasi, menganalisis, menginterpretasikan data kuantitatif dan informasi sains. Literasi sains menurut PISA (2015), adalah suatu kemampuan untuk terlibat dengan isu-isu yang terkait dengan sains dan ide-ide sains. Dengan kata lain, peserta didik dikatakan telah memiliki kemampuan literasi sains apabila mereka mampu mengembangkan konsep-konsep sains atau fakta-fakta sains yang didapatkannya dari berbagai informasi sehingga mampu membangun sebuah pengetahuan atau pemahaman yang baru serta dapat mengaplikasikannya dalam kehidupan sehari-hari. Literasi sains dapat dianggap sebagai dasar dalam pemahaman sains yang dibutuhkan (DeBoer, 2000). Menurut Crowell \& Schunn (2016), literasi sains memiliki banyak arti, yaitu dapat dianggap sebagai pengetahuan dasar, dasar dari keterampilan berpikir kritis atau penerapan dari kedua hal dasar ini (pengetahuan dan keterampilan) untuk membuat keputusan dalam kehidupan sehari-hari.

Pada abad ke-21 ini, kemampuan berliterasi peserta didik berkaitan erat dengan tuntutan keterampilan membaca yang berujung pada kemampuan memahami informasi secara analitis, kritis, dan reflektif. Literasi tidak hanya sekadar membaca dan menulis, namun melibatkan keterampilan berpikir yang membuat mereka literate dalam belajar, termasuk dalam pembelajaran sains. Hal ini sesuai dengan yang dipaparkan oleh Burkhardt et al (2003), bahwa kemampuan literasi tidak hanya sebatas pada kemampuan membaca, mendengar, menulis dan berbicara saja, namun lebih dari itu, kemampuan literasi ditekankan pada literasi yang dapat terkoneksi antara satu dengan lainnya, seperti literasi terhadap kemampuan dasar, sains, teknologi, ekonomi, visual, informasi, multikultural, dan global. DeBoer (2000), mengemukakan bahwa mendidik seseorang untuk melek terhadap sains adalah salah satu dari tujuan utama dalam reformasi pendidikan sains. Hal yang sama juga dipaparkan Eisenhart et al., (1996) tujuan dari literasi sains diharapkan agar dapat memimpin arah reformasi pendidikan sains. Sifat sains dipandang sebagai komponen penting dalam pendidikan sains, yakni hal utama dalam pembelajaran sains di sekolah (Holbrook \& Rannikmae, 2009). Dalam proses pembelajaran sains, diberi penekanan dengan cara pemberian pengalaman langsung untuk mengembangkan kompetensi dalam memperoleh pemahaman yang lebih mendalam tentang alam secara ilmiah. Pembelajaran sains diperlukan dalam kehidupan sehari-hari untuk memenuhi kebutuhan manusia melalui pemecahan masalah-masalah yang dapat diidentifikasikan. Segala permasalahan tersebut dapat dipecahkan jika peserta didik mempunyai literasi sains. Hal yang sama juga dipaparkan (Holbrook \& Rannikmae, 2009), bahwa salah satu target dari pendidikan sains adalah terbentuknya masyarakat yang berliterasi sains.

Peningkatan literasi sains merupakan suatu proyek dasar untuk menciptakan lingkungan inovatif dan menumbuhkan bakat inovatif (Gao et al., 2016). Literasi sains menjadi kunci terakhir dari pendidikan sains selain konsep pengetahuan dan praktis sains secara konvensional (Eisenhart et al., 1996). Oleh karena itu, konsep literasi sains 
nampaknya telah menjadi tujuan utama dari kurikulum pendidikan sains di banyak negara, termasuk Indonesia.

Literasi sains (scientific literacy) kini menjadi tuntutan untuk dikuasai oleh setiap individu baik dalam kehidupan sehari-hari maupun dalam dunia pekerjaan. Individu yang melek sains dapat menggunakan informasi ilmiah yang dimilikinya untuk mengatasi masalah dalam kehidupan seharihari serta meningkatkan kapabilitasnya dalam memegang pekerjaan penting dan menghasilkan produk-produk yang bermanfaat. Oleh karena itu, literasi sains sangat penting dimiliki oleh peserta didik sejak dini. Menurut Kemendikbud (2017), literasi sains membantu peserta didik untuk membentuk pola pikir, perilaku, dan membangun karakter untuk peduli dan bertanggung jawab terhadap dirinya, masyarakat, dan alam semesta, serta permasalahan yang dihadapi masyarakat modern yang sangat bergantung pada teknologi. Menurut Yuliati (2017), dengan literasi sains diharapkan peserta didik mampu memenuhi berbagai tuntutan zaman yaitu menjadi problem solver dengan pribadi yang kompetitif, inovatif, kreatif, kolaboratif, serta berkarakter. Hal tersebut dikarenakan penguasaan kemampuan literasi sains dapat mendukung pengembangan dan penggunaan kompetensi abad 21.

Kemampuan literasi sains anak-anak Indonesia masih tergolong rendah. Hal ini berdasarkan hasil studi Internasional PISA (Programme for International Student Assessment), yang diinisiasi oleh Organisation for Economic Cooperation and Development (OECD). Dimana salah satu aspek yang dinilai adalah literasi sains peserta didik. Dimana menurut (PISA, 2016), Indonesia masih berada pada peringkat 10 terakhir dengan 403 poin pada kompetensi sains pada tahun 2015. Dengan demikian, untuk menumbuhkan budaya literasi di Indonesia, Kementrian Pendidikan dan Kebudayaan menerapkan literasi sebagai salah satu komponen dalam Implementasi Kurikulum 2013 melalui gerakan literasi sekolah. Gerakan Literasi sekolah (GLS) merupakan sebuah upaya yang dilakukan pemerintah secara menyeluruh untuk menjadikan sekolah sebagai organisasi pembelajar yang warganya literate melalui pelibatan publik (Kemendikbud, 2016). Oleh karena itu, melalui implementasi Kurikulum 2013 ini, peserta didik dituntut untuk mengembangkan kemampuan literasi sains yang dimilikinya sehingga kualitas lulusan sekolah menjadi lebih baik, dengan demikian prestasi belajar peserta didik juga menjadi lebih baik.

Berdasarkan hasil penelitian yang dilakukan oleh Lestari (2017) bahwa literasi sains berpengaruh positif terhadap kemampuan kognitif peserta didik. Hal yang sama juga dipaparkan oleh Haristy et al. (2013) bahwa pembelajaran berbasis literasi sains memberikan pengaruh terhadap peningkatan hasil belajar peserta didik. Ini menunjukkan literasi sains dapat meningkatkan prestasi belajar peserta didik.

Sejauh ini belum banyak informasi yang memberikan data tentang keterkaitan antara literasi sains dengan prestasi belajar khususnya pada pembelajaran Kimia di Kota Makassar. Oleh karena itu, perlu dilakukan penelitian untuk mengetahui hubungan antara literasi sains dengan prestasi belajar peserta didik kelas XI MIPA SMA Negeri tahun pelajaran 2017/2018 pada pembelajaran Kimia se-Kota Makassar.

\section{METODE PENELITIAN}

Jenis penelitian ini adalah penelitian "ex-post facto" yang bersifat deskripsi korelasional. Populasi pada penelitian ini adalah seluruh peserta didik kelas XI MIPA SMA Negeri yang ada di kota Makassar tahun ajaran 2017/2018. Penelitian ini dilaksanakan di 7 (tujuh) sekolah SMA Negeri di Kota Makassar yaitu SMA Negeri 2 Makassar, SMA Negeri 4 Makassar, SMA Negeri 5 Makassar, SMA Negeri 8 Makassar, SMA Negeri 12 Makassar, SMA Negeri 15 Makassar, dan SMA Negeri 21 Makassar. Pengambilan sampel dalam 
penelitian ini menggunakan teknik proportionate stratified random sampling. Jadi dari populasi sebanyak 1734 peserta didik, banyaknya sampel yang digunakan dalam penelitian ini adalah 391 peserta didik.

Untuk memperoleh skor variabel penelitian, digunakan instrumen tes literasi sains. Pegumpulan data dilakukan secara langsung yaitu dengan meminta responden untuk mengerjakan tes literasi sains yang berbentuk pilihan ganda dan dibuat berdasarkan indikator literasi sains yang disesuaikan dengan konsep kimia, dan tak langsung dengan mengambil data hasil belajar berupa nilai rapor peserta didik dalam bentuk angka pada mata pelajaran Kimia semester genap tahun pelajaran 2017/2018.

Data dianalisis menggunakan analisis statistik deskiptrif dan analisis statistik inferensial. Data yang diperoleh dari analisis statistik deskiptrif dan analisis statistik inferensial kemudian dikelompokkan berdasarkan kategori pencapaian hasil belajar yang dikemukakan oleh Puspendik Balitbang Kemendikbud pada tahun 2017. Analisis statistik inferensial digunakan untuk menguji kebenaran hipotesis yang diajukan, yakni digunakan analisis korelasi Pearson.

\section{HASIL DAN PEMBAHASAN}

1. Hasil Analisis Statistik Deskriptif

a. Literasi Sains

Kategori nilai literasi sains peserta didik disajikan dalam Tabel 1

\section{Tabel 1 Persentase Nilai Literasi Sains}

\begin{tabular}{|c|c|c|c|}
\hline Interval & $\begin{array}{c}\text { Kategori } \\
\text { Skor }\end{array}$ & Frek & $\begin{array}{c}\text { Persent } \\
\text { ase (\%) }\end{array}$ \\
\hline $85<\mathrm{X} \leq 100$ & Sangat Baik & 0 & 0 \\
$70<\mathrm{X} \leq 85$ & Baik & 89 & 23 \\
$55<\mathrm{X} \leq 70$ & Cukup & 178 & 45 \\
$\mathrm{X} \leq 55$ & Kurang & 124 & 32 \\
\hline \multicolumn{2}{|c|}{ Jumlah } & $\mathbf{3 9 1}$ & $\mathbf{1 0 0}$ \\
\hline
\end{tabular}

Dari Tabel 1 diperoleh hasil literasi sains peserta didik kelas XI MIPA SMA Negeri se-Kota Makassar berada pada kategori cukup dengan persentase $45 \%$ dan frekuensi 178 peserta didik dari 391 peserta.
Gambaran persentase indikator dan kategori nilai literasi sains peserta didik disajikan dalam Tabel 2 berikut.

Tabel 2 Persentase Indikator dan Kategori Nilai Literasi Sains

\begin{tabular}{|c|c|c|c|c|c|}
\hline $\begin{array}{c}\text { Tingkat } \\
\text { an } \\
\text { Literasi } \\
\text { Sains }\end{array}$ & $\begin{array}{c}\text { Indikato } \\
\mathbf{r}\end{array}$ & $\begin{array}{c}\text { Sub } \\
\text { Indikator }\end{array}$ & $\begin{array}{c}\text { Pers } \\
\text { entas } \\
\text { e } \\
(\%)\end{array}$ & $\begin{array}{c}\text { Kat } \\
\text { ego } \\
\text { ri } \\
\text { Nila } \\
\text { i }\end{array}$ & $\begin{array}{c}\text { Pers } \\
\text { entas } \\
\text { e Per } \\
\text { Indi } \\
\text { kato } \\
\text { r } \\
(\%)\end{array}$ \\
\hline $\begin{array}{l}\text { Literasi } \\
\text { Nomina } \\
1\end{array}$ & $\begin{array}{l}\text { Mengide } \\
\text { ntifikasi } \\
\text { konsep } \\
\text { kimia }\end{array}$ & $\begin{array}{l}\text { a. Mengid } \\
\text { entifikas } \\
\text { i istilah } \\
\text { ilmiah } \\
\text { b. Mengid } \\
\text { entifikas } \\
\text { i zat-zat } \\
\text { kimia }\end{array}$ & $\begin{array}{l}65,98 \\
73,15\end{array}$ & $\begin{array}{c}\text { Cuk } \\
\text { up } \\
\text { Bai } \\
\text { k }\end{array}$ & 69,57 \\
\hline $\begin{array}{l}\text { Literasi } \\
\text { Fungsio } \\
\text { nal }\end{array}$ & $\begin{array}{l}\text { Mendefi } \\
\text { nisikan } \\
\text { konsep } \\
\text { kimia }\end{array}$ & $\begin{array}{l}\text { a. Menjela } \\
\text { skan } \\
\text { tentang } \\
\text { konsep } \\
\text { dasar } \\
\text { suatu } \\
\text { materi } \\
\text { b. Menjela } \\
\text { skan } \\
\text { tentang } \\
\text { istilah } \\
\text { ilmiah }\end{array}$ & $\begin{array}{r}42,54 \\
72,89\end{array}$ & $\begin{array}{c}\text { Kur } \\
\text { ang }\end{array}$ & 57,72 \\
\hline $\begin{array}{l}\text { Literasi } \\
\text { konsept } \\
\text { ual dan } \\
\text { prosedu } \\
\text { ral }\end{array}$ & $\begin{array}{l}\text { Menghu } \\
\text { bungkan } \\
\text { antar } \\
\text { konsep } \\
\text { kimia } \\
\text { dalam } \\
\text { memaha } \\
\text { mi suatu } \\
\text { masalah/ } \\
\text { persoala } \\
\text { n }\end{array}$ & $\begin{array}{l}\text { a. Mengint } \\
\text { erpretasi } \\
\text { kan data } \\
\text { b. Mengan } \\
\text { alisis } \\
\text { hubunga } \\
\text { n antar } \\
\text { konsep } \\
\text { kimia }\end{array}$ & $\begin{array}{l}60,02 \\
50,04\end{array}$ & $\begin{array}{c}\text { Cuk } \\
\text { up } \\
\text { Kur } \\
\text { ang }\end{array}$ & 55,03 \\
\hline $\begin{array}{l}\text { Literasi } \\
\text { multidi } \\
\text { mension } \\
\text { al }\end{array}$ & $\begin{array}{l}\text { Menghu } \\
\text { bungkan } \\
\text { konsep } \\
\text { kimia } \\
\text { berdasar } \\
\text { kan } \\
\text { fenomen } \\
\text { a sehari- } \\
\text { hari }\end{array}$ & $\begin{array}{l}\text { a. Menjela } \\
\text { skan } \\
\text { fenomen } \\
\text { a ilmiah } \\
\text { b. Menggu } \\
\text { nakan } \\
\text { bukti } \\
\text { ilmiah }\end{array}$ & $\begin{array}{l}55,24 \\
51,66\end{array}$ & $\begin{array}{l}\text { Kur } \\
\text { ang } \\
\text { Kur } \\
\text { ang }\end{array}$ & 53,45 \\
\hline
\end{tabular}

Berdasarkan Tabel 2, maka dapat dibuat grafik pada Gambar 1 mengenai persentase indikator literasi sains, persentase tingkatan literasi sains disajikan pada Gambar 2, dan persentase dimensi literasi sains disajikan pada Gambar 3. 


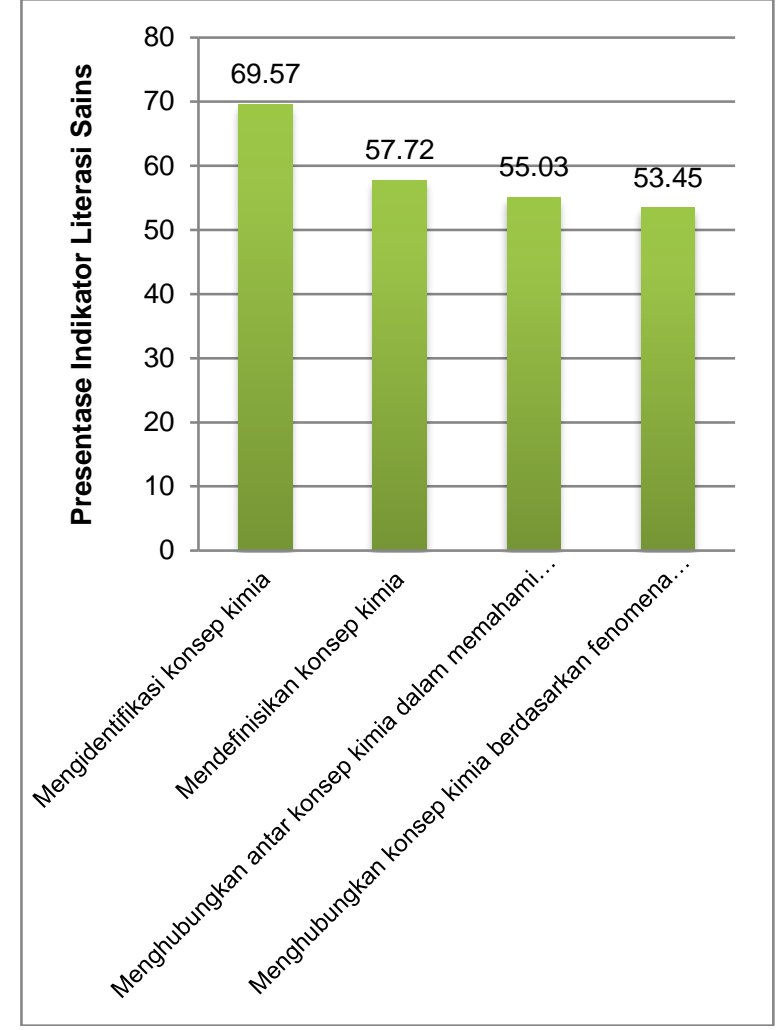

Gambar 1 Persentase Indikator Literasi Sains

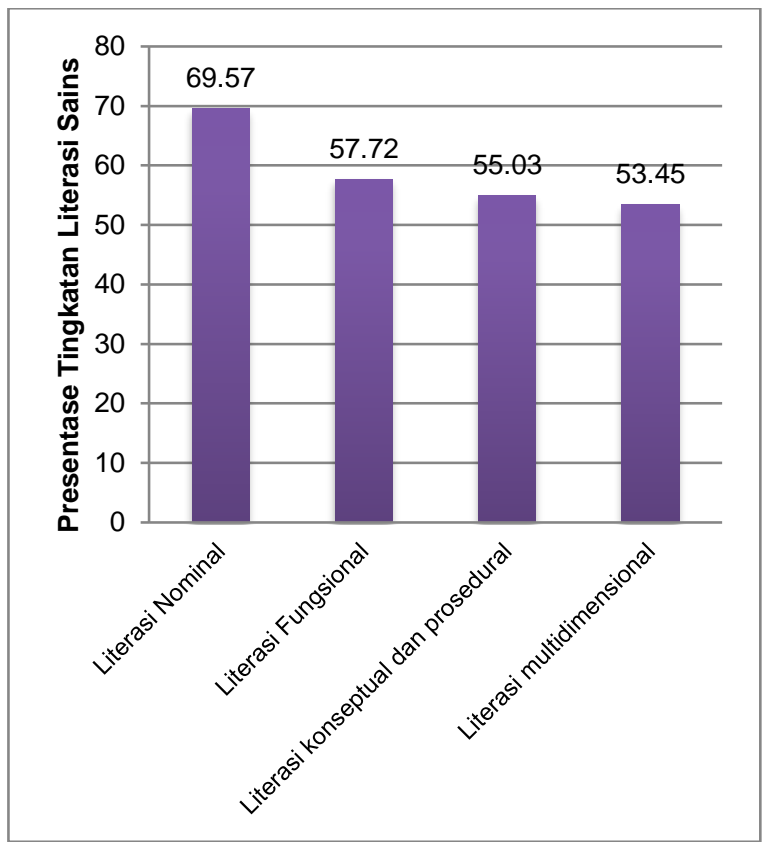

Gambar 2 Persentase Tingkatan Literasi Sains

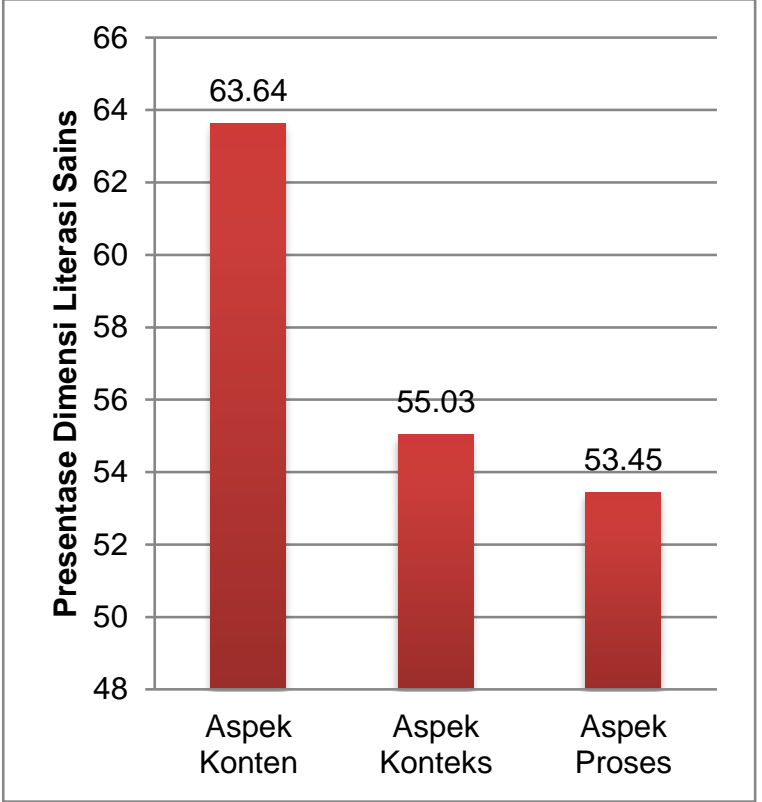

Gambar 3 Persentase Dimensi Literasi Sains

Persentase nilai literasi sains peserta didik pada tiap sekolah penelitian disajikan dalam Tabel 3.

Tabel 3 Persentase Literasi Sains Tiap Sekolah Penelitian

\begin{tabular}{|l|l|l|}
\hline Strata & Nama Sekolah & $\begin{array}{l}\text { Persentase } \\
\text { Literasi } \\
\text { Sains (\%) }\end{array}$ \\
\hline Unggulan & SMAN 2 Makassar & 65,67 \\
& SMAN 5 Makassar & 66,06 \\
\hline Non & SMAN 4 Makassar & 54,75 \\
Unggulan & SMAN 8 Makassar & 46,85 \\
& SMAN 12 Makassar & 46,24 \\
& SMAN 15 Makassar & 59,31 \\
& SMAN 21 Makassar & 61,59 \\
\hline
\end{tabular}

\section{b. Prestasi Belajar}

Kategori nilai prestasi belajar peserta didik disajikan dalam Tabel 4

Tabel 4 Persentase Nilai Prestasi Belajar

\begin{tabular}{|c|c|c|c|}
\hline Interval & $\begin{array}{c}\text { Kategori } \\
\text { Skor }\end{array}$ & Frek & $\begin{array}{c}\text { Perse } \\
\text { ntase } \\
(\%)\end{array}$ \\
\hline $85<X \leq 100$ & Sangat Baik & 96 & 25 \\
\hline $70<X \leq 85$ & Baik & 295 & 75 \\
\hline $55<X \leq 70$ & Cukup & 0 & 0 \\
\hline$X \leq 55$ & Kurang & 0 & 0 \\
\hline \multicolumn{2}{|c|}{ Jumlah } & 391 & 100 \\
\hline
\end{tabular}




\section{Hasil Analisis Statistik Inferensial}

Berikut ini disajikan hasil analisis statistik inferensial yang terdiri atas uji asumsi dan uji hipotesis.

\section{a. Uji Asumsi}

1) Uji Multikolinearitas

$$
\text { Hasil output dari uji }
$$
multikolinearitas menggunakan program IBM SPSS Statistik 21 disajikan dalam Tabel 5.

Tabel 5 Hasil Uji Multikolinearitas

\begin{tabular}{|l|l|}
\hline Variabel & $\begin{array}{l}\text { Collinearity } \\
\text { Statistics }\end{array}$ \\
\cline { 2 - 2 } & VIF \\
\hline Literasi Sains & 1,333 \\
\hline
\end{tabular}

Berdasarkan hasil pengujian dengan SPSS diperoleh nilai Variance Inflation Factor (VIF) variabel Motivasi peserta didik lebih kecil dari $5(V I F<5)$, sehingga dapat dikatakan bahwa antar variabel tidak terjadi persoalan multikolinearitas.

\section{2) Uji Linearitas}

Uji linearitas bertujuan untuk mengetahui apakah dua variabel mempunyai hubungan yang linear atau tidak secara signifikan. Pada taraf signifikan 0,05, dua variabel dikatakan mempunyai hubungan linear nilai signifikansi lebih besar dari 0,05. Tabel 6 disajikan hasil output dari uji linearitas antara variabel bebas dengan variabel terikat menggunakan SPSS.

Tabel 6 Hasil Uji Linearitas Antara Variabel

\begin{tabular}{|l|l|}
\hline Variabel & $\begin{array}{l}\text { Deviation from } \\
\text { Linearity (Sig.) }\end{array}$ \\
\hline $\begin{array}{l}\text { Literasi Sains dengan } \\
\text { Prestasi Belajar }\end{array}$ & 0,234 \\
\hline
\end{tabular}

Berdasarkan Tabel 6 diperoleh nilai signifikansi (Deviation from Linearity) lebih besar dari $\alpha=0,05$ yang berarti terdapat hubungan linear secara signifikan antara variabel literasi sains dengan prestasi belajar.

\section{b. Uji Hipotesis}

Pengujian hipotesis menggunakan analisis korelasi Pearson dan uji t. Hasil uji hipotesis dengan korelasi Pearson dan uji t menggunakan program SPSS disajikan dalam Tabel 7 dan Tabel 8.

Tabel 7 Hasil Analisis Korelasi Pearson

\begin{tabular}{|lr|l|l|}
\hline Variabel & $\begin{array}{l}\text { Pearson } \\
\text { Correlati } \\
\text { on }\end{array}$ & $\begin{array}{l}\text { Tingkat } \\
\text { Korelasi }\end{array}$ \\
\hline $\begin{array}{l}\text { Literasi } \\
\text { dengan Sains } \\
\text { Belajar }\end{array}$ & 0,487 & Sedang \\
\hline
\end{tabular}

Tabel 8 Hasil Analisis Uji t

\begin{tabular}{|l|l|}
\hline Variabel & Uji t \\
\hline $\begin{array}{l}\text { Literasi Sains dengan } \\
\text { Prestasi Belajar }\end{array}$ & 8,192 \\
\hline
\end{tabular}

Tabel 9 Hubungan Sub Indikator Literasi Sains dengan Prestasi Belajar

\begin{tabular}{|c|c|c|c|}
\hline Sub Indikator & Beta & Sig. & $\begin{array}{l}\text { Keteran } \\
\text { gan }\end{array}$ \\
\hline $\begin{array}{l}\text { 1a. } \\
\text { Mengidentifikasi } \\
\text { istilah ilmiah }\end{array}$ & $\begin{array}{l}0,22 \\
1\end{array}$ & $\begin{array}{l}0,00 \\
0\end{array}$ & $\begin{array}{l}\text { ada } \\
\text { pengaru } \\
\mathrm{h}\end{array}$ \\
\hline $\begin{array}{l}\text { 1b. } \\
\text { Mengidentifikasi } \\
\text { zat kimia }\end{array}$ & $\begin{array}{l}0,11 \\
1\end{array}$ & $\begin{array}{l}0,02 \\
1\end{array}$ & $\begin{array}{l}\text { ada } \\
\text { pengaru } \\
\mathrm{h}\end{array}$ \\
\hline $\begin{array}{l}\text { 2a. Menjelaskan } \\
\text { tentang konsep } \\
\text { dasar suatu materi }\end{array}$ & $\begin{array}{l}- \\
0,04 \\
3\end{array}$ & $\begin{array}{l}0,33 \\
6\end{array}$ & $\begin{array}{l}\text { tidak } \\
\text { ada } \\
\text { pengaru } \\
\mathrm{h} \\
\end{array}$ \\
\hline $\begin{array}{l}\text { 2b. Menjelaskan } \\
\text { tentang istilah } \\
\text { ilmiah }\end{array}$ & $\begin{array}{l}0,09 \\
1\end{array}$ & $\begin{array}{l}0,06 \\
9\end{array}$ & $\begin{array}{l}\text { tidak } \\
\text { ada } \\
\text { pengaru } \\
\text { h }\end{array}$ \\
\hline $\begin{array}{l}\text { 3a. } \\
\text { Menginterpretasik } \\
\text { an data }\end{array}$ & $\begin{array}{l}0,21 \\
5\end{array}$ & $\begin{array}{l}0,00 \\
0\end{array}$ & $\begin{array}{l}\text { ada } \\
\text { pengaru } \\
\mathrm{h}\end{array}$ \\
\hline $\begin{array}{l}\text { 3b. Menganalisis } \\
\text { hubungan antar } \\
\text { konsep kimia }\end{array}$ & $\begin{array}{l}0,07 \\
2\end{array}$ & $\begin{array}{l}0,11 \\
2\end{array}$ & $\begin{array}{l}\text { tidak } \\
\text { ada } \\
\text { pengaru } \\
\mathrm{h} \\
\end{array}$ \\
\hline $\begin{array}{l}\text { 4a. Menjelaskan } \\
\text { fenomena ilmiah }\end{array}$ & $\begin{array}{l}0,14 \\
8\end{array}$ & $\begin{array}{l}0,00 \\
2\end{array}$ & $\begin{array}{l}\text { ada } \\
\text { pengaru } \\
\mathrm{h}\end{array}$ \\
\hline $\begin{array}{l}\text { 4b. Menggunakan } \\
\text { bukti ilmiah }\end{array}$ & $\begin{array}{l}0,09 \\
7\end{array}$ & $\begin{array}{l}0,03 \\
6\end{array}$ & $\begin{array}{l}\text { ada } \\
\text { pengaru } \\
\mathrm{h}\end{array}$ \\
\hline
\end{tabular}

Setelah uji hipotesis maka dilakukan analisis jalur untuk melihat pengaruh satu variabel bebas terhadap variabel terikat berdasarkan indikator. Hasil analisis jalur ditunjukkan pada Tabel 9. 


\section{Pembahasan Hasil Penelitian}

Berdasarkan hasil uji hipotesis pada Tabel 10 dapat dikatakan bahwa terdapat korelasi atau hubungan antara literasi sains dengan prestasi belajar peserta didik dimana korelasi berada pada tingkat korelasi sedang. Pada Tabel 11, hasil analisis regresi ganda diperoleh nilai $t_{\text {hitung }}=8,192$ lebih besar dari $\mathrm{t}_{\text {tabel }}=1,966$, maka $\mathrm{H}_{0}$ ditolak dan $\mathrm{H}_{1}$ diterima artinya terdapat korelasi antara literasi sains dengan prestasi belajar peserta didik pada tingkat korelasi sedang. Adapun hubungan kedua variabel tersebut adalah signifikan yang artinya prestasi belajar peserta didik dipengaruhi oleh literasi sains peserta didik itu sendiri. Hal ini sejalan dengan penelitian sebelumnya yang dilakukan oleh Haristy et al. (2013) bahwa pembelajaran berbasis literasi sains memberikan pengaruh dengan peningkatan hasil belajar peserta didik. Hal yang sama juga dipaparkan oleh Nugraheni et al., (2017) yang menunjukkan bahwa ada hubungan positif antara kemampuan literasi sains dan hasil belajar peserta didik, yang artinya semakin tinggi kemampuan literasi sains maka semakin tinggi hasil belajar peserta didik. Ini menunjukkan bahwa literasi sains dapat meningkatkan prestasi belajar peserta didik.

Berdasarkan Gambar 2 menunjukkan bahwa kemampuan literasi sains peserta didik pada pembelajaran Kimia Kelas XI MIPA SMA Negeri se-Kota Makassar masih berada pada tingkatan literasi nominal, yaitu pada tingkatan dalam mengenali istilahistilah kimia atau konsep kimia sedangkan kemampuan peserta didik dalam menghubungkan konsep kimia dengan fenomena sehari-hari, yang merupakan bagian dari tingkatan literasi multidimensional masih tergolong cukup rendah dibandingkan tingkatan literasi sains lainnya. Rendahnya kemampuan peserta didik dalam menghubungkan konsep kimia berdasarkan fenomena sehari-hari disebabkan karena kemampuan peserta didik dalam menguasai konsep dasar suatu materi masih dalam kategori kurang, yang ditunjukkan dalam Tabel 5 sebesar 42,54\% sehingga kurangnya penguasaan konsep dasar inilah yang menyebabkan peserta didik masih mengalami kesulitan dalam menghubungkan konsep kimia berdasarkan fenomena sehari-hari. Hal ini juga ditunjukkan dari kemampuan literasi sains peserta didik pada Gambar 3 yang berada pada aspek konten sebesar $63,64 \%$, yang merujuk pada konsep-konsep sains yang diperlukan untuk memahami fenomenafenomena alam, dan merupakan bagian dari kategori tingkatan literasi nominal. Sedangkan aspek proses literasi sains masih tergolong cukup rendah yaitu sebesar $53,45 \%$, yang merujuk pada proses mental yang terlibat ketika menjawab suatu pertanyaan atau memecahkan suatu permasalahan, dan merupakan bagian dari kategori tingkatan literasi multidimensional.

Penelitian ini sejalan dengan penelitian yang dilakukan Celik (2014) yang menunjukkan bahwa hasil literasi nominal dan konseptual peserta didik menunjukkan pencapaian yang memuaskan dalam harapan untuk kurikulum baru tetapi untuk hasil penilaian literasi fungsional dan multidimentional yang diperoleh peserta didik masih belum mencukupi. Hasil penelitian serupa juga dilakukan oleh Odja dan Payu (2014), yang meneliti tentang analisis kemampuan awal literasi sains peserta didik pada konsep IPA dan diperoleh hasil bahwa kemampuan literasi peserta didik lebih besar pada kategori literasi nominal yaitu pada rentang 54\%-95\%, literasi fungsional memperoleh persentase kecil yaitu pada rentang 4\%-9\% dan untuk kategori literasi konseptual dan multidimensional berada pada persentase $0 \%$.

Berdasarkan analisis jalur hubungan setiap sub indikator literasi sains dengan prestasi belajar peserta didik, diketahui bahwa dari delapan sub indikator literasi sains, terdapat lima sub indikator yang mempengaruhi prestasi belajar peserta didik seperti yang ditunjukkan pada Tabel 12 yaitu indikator mengidentifikasi istilah 
ilmiah, mengidentifikasi zat kimia, menginterpretasikan data, menjelaskan fenomena ilmiah dan menggunakan bukti ilmiah. Sub indikator yang memiliki pengaruh paling besar adalah sub indikator mengidentifikasi istilah ilmiah dengan nilai koefisien Beta sebesar 0,221. Sub indikator mengidentifikasi istilah ilmiah dan mengidentifikasi zat kimia merupakan bagian dari indikator mengidentifikasi konsep kimia, yang menjelaskan tingkatan literasi nominal dan termasuk dalam aspek konten literasi sains. Dengan demikian, aspek konten literasi sains khususnya pada tingkatan literasi nominal adalah tingkatan literasi sains yang paling mempengaruhi prestasi belajar peserta didik kelas XI MIPA SMA Negeri se-Kota Makassar.

\section{SIMPULAN DAN SARAN}

Berdasarkan hasil analisis data penelitian dan pembahasan hasil penelitian, maka kesimpulan dari hasil penelitian ini adalah terdapat hubungan antara literasi sains dengan prestasi belajar peserta didik pada pembelajaran Kimia Kelas XI MIPA SMA Negeri se-Kota Makassar dengan tingkat korelasi sedang, dan sub indikator literasi sains yang memiliki pengaruh paling besar terhadap prestasi belajar adalah sub indikator mengidentifikasi istilah ilmiah.

\section{DAFTAR RUJUKAN}

Abdullah, M. \& Osman, K. 2010. 21st Century Inventive Thinking Skills among Primary Students in Malaysia and Brunei. Procedia-Social and Behavioral Sciences, 9: 1646-1651.

Burkhardt, G., Monsour, M., Valdez, G., Gunn, C., Dawson, M., Lemke, C., Coughlin, E., Thadani, V., Martin, C., 2003. EnGauge 21st Century Skills: Literacy in the Digital Age. NCREL and METIRI Group, USA.

Celik, S., 2014. Chemical Literacy Levels of Science and Mathematics Teacher Candidates. Aust. J. Teach. Educ.
Online 39, 1. https://doi.org/10.14221/ajte.2014v3 9n1.5

Crowell, A. \& Schunn, C. 2016. Unpacking The Relationship Between Science Education and Applied Scientific Literacy. Research in Science Education, 46(1): 129-140.

DeBoer, G.E. 2000. Scientific literacy: Another Look at Its historical and Contemporary Meanings and Its Relationship to Science Education Reform. Journal of Research in Science Teaching, 37(6): 582-601.

Eisenhart, M., Finkel, E. \& Marion, S.F. 1996. Creating the Conditions for Scientific Literacy: A ReExamination. American Educational Research Association and SAGE Publications, 33(2): 261-295.

Gao, H., He, W., Zhang, C. \& Ren, L. 2016. Building scientific literacy in China: achievements and prospects. China Research Institute for Science Popularization, 61(11): 871-874.

Gormally, C., Brickman, P. \& Lutz, M. 2012. Developing a Test of Scientific Literacy Skills (TOSLS): Measuring Undergraduates' Evaluation of Scientific Information and Arguments. CBE-Life Sciences Education, 11(4): 364-377.

Haristy, D.R., Enawaty, E., Lestari, I., 2013. Pembelajaran Berbasis Literasi Sains pada Materi Larutan Elektrolit dan Non Elektrolit di SMA Negeri 1 Pontianak. J. Pendidik. Dan Pembelajaran 2.

Holbrook, J. \& Rannikmae, M. 2009. The Meaning of Scientific Literacy. International Journal of Environmental and Science Education, 4(3): 275-288. 
Kemendikbud. 2016. Penguatan Literasi Dalam Pembelajaran. Jakarta: Kementrian Pendidikan dan Kebudayaan.

Kemendikbud. 2017. Materi Pendukung Literasi Sains. Jakarta: Kementrian Pendidikan dan Kebudayaan.

Lestari, I.D., 2017. Pengaruh Literasi Sains Terhadap Kemampuan Kognitif Siswa Pada Konsep Ekosistem, in: Prosiding Seminar Nasional Pendidikan FKIP UNTIRTA 2017. Presented at the Seminar Nasional Pendidikan FKIP UNTIRTA 2017, Serang, pp. 103-106.

National Research Council, 1996. National Science Education Standards. National Academies Press, Washington DC.

Nugraheni, D., Suyanto, S., Harjana, T., 2017. Pengaruh Siklus Belajar 5E Terhadap Kemampuan Literasi Sains Pada Materi Sistem Saraf Manusia. Prodi Pendidik. Biol. 6, 178-188.

Odja, A.H., Payu, C.S., 2014. Analisis Kemampuan Awal Literasi Sains Siswa Pada Konsep IPA, in: Prosiding Seminar Nasional Kimia. Presented at the Prosiding Seminar Nasional Kimia, Jurusan Kimia FMIPA Universitas Negeri Surabaya, Surabaya, pp. 40-47.

PISA. 2016. Country Note - Results from PISA 2015. OECD. www.oecd.org.edu/pisa.

PISA. 2015. Draft Science Framework. PISA OECD.
Puspendik Balitbang Kemendikbud, 2017. Panduan Pemanfaatan Hasil Ujian Nasional Tahun Pelajaran 2016/2017 untuk Perbaikan Mutu Pendidikan. Puspendik Balitbang Kemendikbud, Jakarta.

Sugiyono. 2016. Metode Penelitian Kuantitatif, Kualitatif dan $R \& D$. Bandung: Alfabeta.

Yuliati, Y. 2017. Literasi Sains Dalam Pembelajaran IPA. Jurnal Cakrawala Pendas, 3(2): 21-28. 